ENTREPRENEURSHIP AND SUSTAINABILITY ISSUES

ISSN 2345-0282 (online) http://jssidoi.org/jesi/ 2019 Volume 7 Number 1 (September)

http://doi.org/10.9770/jesi.2019.7.1(29)

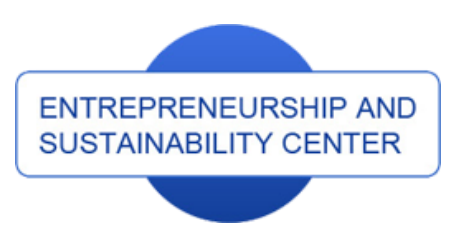

Publisher

http://jssidoi.org/esc/home

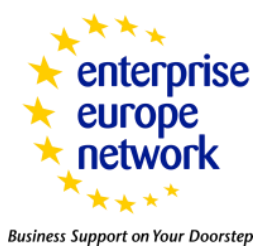

CASPA

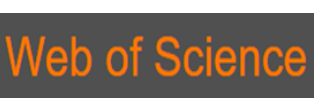

1) Clarivate

\title{
THE INFLUENCE OF SELF-CONTROL, TIME PRESSURE, INFORMATION ALTERNATIVES, AND STOCK OUT ON CONSUMPTION DELAY
}

\author{
Dyah Sugandini ${ }^{1}$, Christin Susilowati ${ }^{2}$, Argo Pambudi ${ }^{3}$, Suranto Aw ${ }^{4}$, Muafi Muafi ${ }^{*}$, Mukarto Siswoyo ${ }^{6}$ \\ ${ }^{1}$ Universitas Pembangunan Nasional Veteran Yogyakarta, Jl. SWK 104 Condong Catur Yogyakarta, Indonesia \\ ${ }^{2}$ Universitas Brawijaya, Jl. MT. Haryono Malang, Indonesia \\ ${ }^{3,4}$ Universitas Negeri Yogyakarta, Jl. Colombo KarangMalang Catur Tunggal Yogyakarta, Indonesia \\ ${ }^{5}$ Universitas Islam Indonesia, Jl. SWK Condong Catur Yogyakarta, Indonesia \\ ${ }^{6}$ Universitas Swadaya Gunung Djati, Jl. Pemuda Sunyaragi Cirebon, Indonesia
}

E-mail: corresponding author: ${ }^{5 *}$ muafi@uii.ac.id

Received 15 March 2019; accepted 25 July 2019; published 30 September 2019

\begin{abstract}
This study examines the delay model that is influenced by information alternatives, time pressure, self-control, and stock out. It also examines consumer response after delay occurred. The focus of this research is on the internal and external aspects, with individual as the analysis unit. The respondents of this research are 165 consumers in Generation Z. This research uses several product categories, such as laptop, hand phone, and fashion (with types of famous branded jeans, bag, shoes, and t-shirt). The respondents age range from 18-25 years old. The sampling technique used is purposive sampling. The sample requirement is the one who have postponed consumption and have relatively good self-control. The model in this research is analyzed using two step approach to Structural Equation Modeling (SEM).The research result shows that some hypothesis that relate the factor that can affect consumption delay, including time pressure, stock-out, selfcontrol, and response after conducting consumption delay are supported. Only the effect of alternative information on delay that was not supported.
\end{abstract}

Keywords: self control; time pressure; information alternative; stock out; delay

Reference to this paper should be made as follows: Sugandini, D.; Susilowati, Ch.; Pambudi, A.; Aw, S.; Muafi, Siswoyo, M. 2019. The influence of self-control, time pressure, information alternatives, and stock out on consumption delay, Entrepreneurship and Sustainability Issues 7(1): 413-424. http://doi.org/10.9770/jesi.2019.7.1(29)

JEL Classifications: E21

\section{Introduction}

The Indonesian Central Bureau of Statistics recorded the inflation of June 2018 is $0.59 \%$. The inflation of $0.59 \%$ in June makes the inflation in the calendar year from January-May 2018 of 1.90\% and year on year (yoy) 3.12\%. The inflation in Indonesia has caused a decline in people's purchasing power and the tendency of people to delay 


\section{ENTREPRENEURSHIP AND SUSTAINABILITY ISSUES}

ISSN 2345-0282 (online) http://jssidoi.org/jesi/ 2019 Volume 7 Number 1 (September) http://doi.org/10.9770/jesi.2019.7.1(29)

their purchases, even though the product is very much needed. Consumers tend to keep using their old items as effectively as possible and keep trying to use them although the product should be replaced. For example, tire product that usually have 5-year expiration, but since the prices tend to rise and become expensive, people extend the use of tires up to 7 years. This also happens with fashion products. Fashion products that still can be used will not be replaced by a new product. The decline of purchasing power causes some consumers to tend to delay their purchase as a consequence of making savings due to the inflation. Purchase delay in Indonesian society has been carried out since two years ago (2017). The decline in purchasing power in lower middle class can actually occur. Changes in spending patterns, especially delays in purchasing durable goods can affect the income of the lower middle class. It is also explained that the decline in purchasing power is experienced by the lower middle class groups along with the decline in real income. In the upper middle class community groups, the thing that occurs is a combination between delaying consumption and changing consumption into saving. This is inseparable from the decline in their confidence in consumption (spending) in the middle of economic conditions that are considered uncertain (Detikfinance, 2018).

This research explains the concept of delayconsumption as a part of aspect in consumer behavior. Purchase delay is usually a strong tendency of one's nature (Odum, 2011) and it is consistent without intervention (Kirby, 2009). An individual considers purchasing delay by taking into account other possible outcomes of the delay (Friedel, DeHart, Madden, \& Odum, 2014). DeHart and Odum (2015) stated that framing the delay aims to get a long-term benefits. Besides that, DeHart, Friedel, Frye, Galizio, and Odum (2017) stated that framing the delay's possible to account for delay uncertainty.

There are several issues raised in this research that explain the importance of delay consumption concept. The issues are positive discounting versus negative discounting, delay effect, self-control phenomenon, affection, and situation. The concept of positive discountingin finance can be used to explain consumer behavior. This concept shows that consumer will immediately use the money available to buy something. In other words, consumer cannot resist making immediate purchases and consuming them. Louweinsten (1987) argued that this concept cannot be used thoroughly to explain consumer behavior. Positive discounting is not always applied by consumers in spending their money. In this case, the concept of negative discounting explains that consumers can resist to not spending their money immediately. Consumers delay consumption for a product or service. This concept also shows that consumer can anticipate what will happen in the future. Consumers do an act of saving to keep things going in the future (Sugandini et al, 2018). Regarding with real consumer behavior, they are able to resist from being tempted to make purchase immediately (Hirsh, et al., 2010). When linked to the concept of impulse buying which have received much attention (Rook, 1987), the concept of delay consumption is at its extreme point (Sugandini et al., 2018). This means that this concept is something that is the opposite. The concept of impulse buying can be explained by positive discounting, while delay consumption can be explained by negative discounting. The concept of impulse buying is easily occurred because of several things, such as physical proximity, temporal proximity, and social comparison (Hoch \& Loewenstein, 1991). Delay consumption occurs because there is a mechanism of self-control in consumer (Hoch \& Lowenstein, 1991; Gast \& Ledford, 2014). Self-control is the one that manage consumer to not easily let themselves to use their money. In the consumer's self, there is a mechanism to reduce the desire to consume and avoid regret in the future. Some of the mechanisms that will be discussed in this case are the concepts of avoidance, higher authority, and pre-commitment. Another concept that can explain delayconsumption is structure delay. Structure delay is related with several things such as time pressure and information alternative (Greenleaf \& Lehmann, 1995). Another factor that is no less important in influencing delay purchase is situational factor. According to Joseph (2005), situational factor is able to provide direction as to why a consumer rejects or delay a purchase. This situational factor is important to be understood in this research, because this aspect is the variable that explains directly about consumer behavior without having to search for further information. 


\section{ENTREPRENEURSHIP AND SUSTAINABILITY ISSUES}

ISSN 2345-0282 (online) http://jssidoi.org/jesi/ 2019 Volume 7 Number 1 (September) http://doi.org/10.9770/jesi.2019.7.1(29)

The concept of delayconsumption also has an effect toward consumer affection. There is a difference of opinion on the effect of consumer affection delay consumption. Hui et al., (1998) argued that consumer will have negative affection if they perceive the time of fulfillment for a long desired goal. A person will experience anxiety and stress. However, the research that is conducted by Nowlis et al., (2004) shows that delays consumption can increase its own pleasure. The concept of delay is not always having negative effect toward consumer. But, there are some conditions that cause consumers can experience a delay situation. First, if consumers delay consumption of products that are hedonic or pleasant, customers do not perceive that delay is an unpleasant thing. Second, consumers do not feel that delay is something resent if they have the certainty to consume it. In other words, consumers are not only imagining consuming the product or service. Third, if the product that is delayed in its consumption is around us, then consumers would not perceive the delay. Fourth, Shu (2005) argued that delay is not a problem for someone if they are looking for the right time to consume it in the future. Consumers will not get pleasure if they consume it immediately. This research aims to explore and analyze the factors explaining about delayconsumption. This research examines the model of delayconsumption that focuses on the internal and external aspects of individual. This research also tests about the relationship between self-control and delay consumption structure that consists of time pressure, perceived stock out, and information alternative, and also examines the impact of decision of delay consumption toward consumer affection response.

The last issue that is discussed in this research is related with delay behavior carried out by consumers in the category of Generation Z. Consumers in Generation Z born between the years of 1995-2012. This generation is raised in the dominance of the use of information technology or net generation. This net generation is a very smart generation of technology and most of them use the internet as the main media (Lippincott, 2005). Delay usually occurs frequently to these consumers, because they are faced with many choices of online outlets and are not limited by time to make a purchase decision.

\section{Literature review and hypotheses}

Baumann \& Odum, (2012) showed evidence that delay is a group of various psychological processes. For example, time perception, memory capacity (Wesley \&Bickel, 2014) and one's intelligence (Shamosh et al., 2008). But, Killeen (2015) stated that the relationship of most of theoretical models only weakly explains psychological processes. The research conducted by Sugandini (2013) related to consumption delay in Indonesia shows that most consumers delay purchases because of high self-control before deciding on a purchase. Psychological factors that drive a person to postpone a purchase are fear of a wrong purchasing decision, which cause consumers in Indonesia prefer to delay their purchases. Another factor that causes consumers in Indonesia delay their purchases is the economic value of the products sold. The high rate of inflation causes a person to feel the need to recalculate the item to be bought because of increasing price. Paglieri, Addessi, Sbaffi, Tasselli, and Delfino (2015) theorized that delay is not caused by differential effect of consumption delay, but it is a result of motivation to maximize the delay outcome. In the end, we found the significant delay discount. DeHart (2017)found that delay is significantly correlated with outcome. Several prior researches also found that delay has a correlation with outcome differently (Friedel, et al., 2014, 2015) and delay framing condition (DeHart \& Odum, 2015). The research result conducted by DeHart (2017) also explained that individuals who delay their consumption will reframe their choice by pushing a better self-control. This research proposes several factors that can affect consumption delay, including information alternative, time pressure, stock-out, self-control, and response after delaying purchases. 


\section{ENTREPRENEURSHIP AND SUSTAINABILITY ISSUES}

ISSN 2345-0282 (online) http://jssidoi.org/jesi/

2019 Volume 7 Number 1 (September)

http://doi.org/10.9770/jesi.2019.7.1(29)

\subsection{Information Alternative and Delayed Consumption}

Greenleaf \& Lehmann (1995) stated that people delay to get more information about the product. Consumer will feel more satisfied and not confused about his decision when they get more information about the product (Jacoby, Speller and Kohn, 1974). Consumers continuously collect information if the cost of getting the information is smaller than the benefits they receive. The less information alternatives obtained by consumers, they will strengthen their decision to delay the purchases.

Hypothesis 1: Information Alternative has an influence toward onsumption delay

\section{2. time pressure and delayed consumption}

Greenleaf and Lehmann (1995) showed the main reason of the delay of decision making is because consumpers perceive that they don't spend enough time on their decision, they feel that buying a product is an unpleasant job, and they try to avoid it. Dhar and Nowlis (1999) conducted a research with the aim to test the effect of time pressure toward choice deferral. The result shows that when a conflict occurs, time pressure will decrease choice deferral with increasing attention to the unique appearance of a product. Besides, consumers in net generation have much time in choosing product because their purchasing can be done online. If these consumers feel that they do not have enough time to choose products, then they tend to delay it since the chance and time to choose products can be done anytime and anywhere through their gadget. The perception of time pressure has an impact on the decision to delay the purchase.

Hypothesis 2: Time Pressure has an influence toward consumption delay

\subsection{Stock out and delayed consumption}

Fitszimon (2000) shows a theory of psychological reactance which stated that when individual's freedom to choose is limited by the elimination of certain behaviors, the individual will give certain psychological reactions, namely an increase in certain aggressive activities. Stockout is a problem that is often complained of by many consumers, so it will have an impact on the delay consumption by the consumers. To strengthen this argument, Sugandini (2013) stated that when individual's freedom to choose is limited by the elimination of certain behaviors, they will give certain psychological reaction namely an increase in certain aggressive activities.

Hypothesis 3: Perception of Stockout has an influence toward consumption delay

\subsection{Self-control and delayed consumption}

Baumeister (2002) defined self-control and self-regulation as a capacity to give condition alternative and certain response. Kivetz and Simonson (2002) explained thatself-control is a result of one's effort to hold back and limit future behavior from a number of choices. This behavior is also called as pre-commitment or anticipatory selfcommand. Someone who has a high self-control has the ability to delay consumption. Individuals try to resist from influencing aspects to immediately buy a product or service by trying to avoid, delay, divert attention, and discipline by making life principles (Kivetz and Simonson, 2002).

Hypothesis 4: Self-controlhas an influence toward consumption delay

\subsection{Delayed consumption and response}

Hui, Thakor and Gill (1998) showed the reaction or response from consumers toward their delay of making decision. Emerging reactions are: perceived waiting time, affective response, and service evaluation. In many literature, the relationship between types of delay with perceived waiting time and affective response have not been specified clearly. Delay is explicitly assumed to have an influence to affective response and perceived waiting time (Hornick, 1984). 


\section{ENTREPRENEURSHIP AND SUSTAINABILITY ISSUES}

ISSN 2345-0282 (online) http://jssidoi.org/jesi/ 2019 Volume 7 Number 1 (September) http://doi.org/10.9770/jesi.2019.7.1(29)

Nowlis, et al., (2004) presented the influence of delay consumption toward consumption enjoyment. Osuna (1985) stated that there is an increase in stress and anxiety in waiting, and this stress can decrease consumer evaluation of their consumption experience. Nowlis et al., (2004) shows two consequences of delay on consumption enjoyment. First, consumers can anticipate product consumption in the future which might be fun if the results they enjoy are positive. Second, consumers who experience delay will feel frustrated and restless. Delay will have negative consequence toward consumption enjoyment. First, the theory of discounted utility that assumes a positive discount rate so that consumers tend to choose consumption as soon as possible rather than delay (Loewnstein and Prelec, 1992). In other words, consumers will not enjoy if they have to delay. Second, delay can cause anxiety and stress. It was further stated that this could occur in utilitarian products, but not in hedonic products (Hirschman and Holbrook, 1982)

Hypothesis 5: The decision of consumption delay has an influence toward consumer response.

\section{Research method}

The population of this research is all consumersof $\mathrm{Z}$ generation in Province of the Special Region of Yogyakarta (DIY), Indonesia that have delayed the purchase of a product from the last 3 months. This time limitation is determined because it relates to the respondents' ability to remember their psychological condition when buying products in the past one year. According to Menon et al., (1995), researchers must pay attention to the aspect of recall dependency. This means that researchers must pay attention to whether the questions posed by respondents are still within the limits of memory. If the question items ask something that has happened a little while ago, then the individual will have difficulty to remember the event that was asked in the questionnaire. The settings of this research are applied to certain product categories. Based on the result of exploratory research, the products that will be used in this research are laptop, hand phone, and fashion (with types of famous branded jeans, bag, shoes, and t-shirt). Based on the exploratory research, the products were chosen because they have a high frequency to be purchased by consumers at the age of 18-25 years old, and those products are the most often delayed.

The sampling technique that is used in this research is purposive sampling. This sampling has a non-probability aspect that meets certain criteria (Cooper and Schindler, 2003). These criteria are consumers who have postponed consumption and have relatively good self-control. The model that is used to analyze the data in this research is two step approaches to Structural Equation Modeling (SEM). The variable measurement model that is used in this research is Confirmatory Factor Analysis. The confirmatory factor analysis is conducted by researchers using the statistic application program, namely AMOS 21. There are six main constructs: information alternative, time pressure, stock out, self-control, delay consumption, and response that have 27 questionnaire items. The evaluation toward the model test result is good fit model. The evaluation result of the proposed model shows that all of the criteria that are used mostly show good results, which means that the model is good so that it can be accepted.

\section{Results and discussion}

\subsection{Description of research respondents}

This research shows that from 165 consumers that is used as respondents, $51.4 \%$ of them are male and $48.6 \%$ are female. The respondents in this research have an age range from 18 to 24 years old. Based on the amount of allowance per month, the average respondents have an allowance of $\mathrm{Rp} \mathrm{1.000.000} \mathrm{-} \mathrm{Rp} \mathrm{1.500.000.} \mathrm{The}$ information about the average allowance is aims to find out that they have enough ability to buy products.

This research is using the data collected from 165 consumers in Province of the Special Region of Yogyakarta (DIY), Indonesia. The data is obtained using questionnaire instrument equipped with in-depth interview. Before 
the questionnaire is used in the research, 30 consumers that is planned to become respondents were tested. After that, the validity and reliability of instruments were tested. From the analysis result, it is known that the questionnaire items presented are valid and reliable, so the questionnaire is distributed to 200 respondents based on the predetermined sample. Out of 200 distributed questionnaires, there are 165 respondents collected. This has fulfilled the requirements to be analyzed using Structural Equation Modeling as suggested by Hair (1998) and Bentler (1995).

\subsection{Model evaluation using Two-Step Approach to SEM}

The test result using structural equation model with AMOS program can be seen on Figure 1.

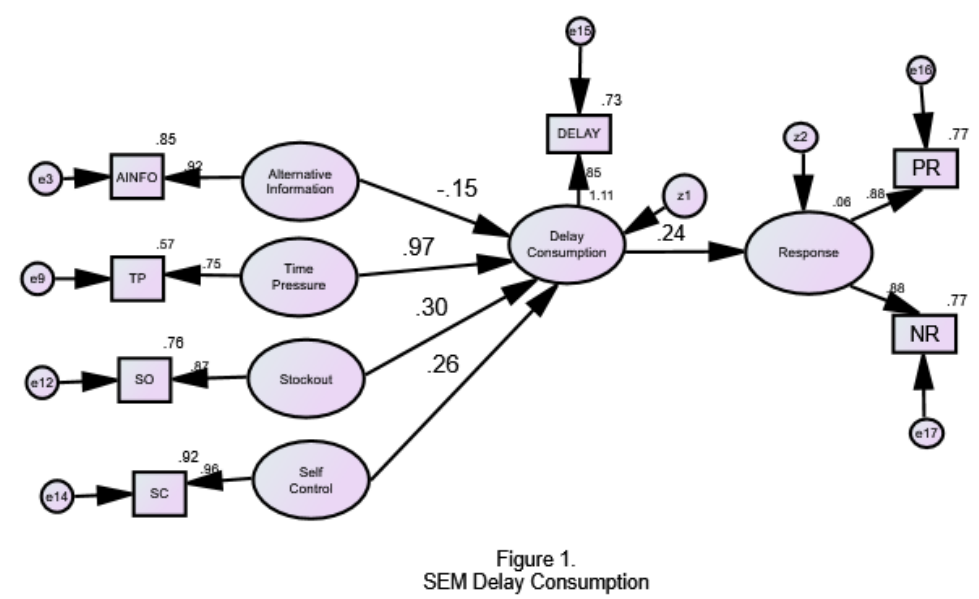

In order to test the hypothesis of causal relationship between information alternative, time pressure, stock out, self-control, delay decision, and response, it is presented the path coefficient that shows the causal relationship between these variables. These relationships are shown in Table 1.

Table1. Path Coefficient (Standardize Regression) between Variables

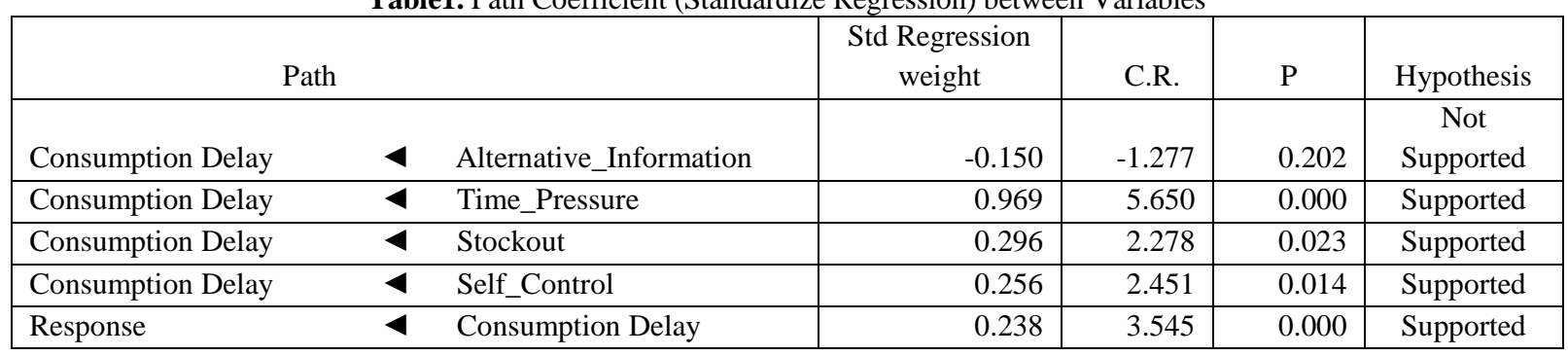

The hypothesis test is done by looking at the CR value. The CR value is significant if the CR value is $>2$. With this criteria, it can be seen all paths are insignificant. Information alternative have no significant influence toward consumption delay, time pressure has an influence toward consumption delay, stockout has an influence toward delayconsumption, self-controlhas an influence toward consumption delay, and consumption delay has a significant influence toward response perceived by consumers after delaying their purchase. 


\section{ENTREPRENEURSHIP AND SUSTAINABILITY ISSUES}

ISSN 2345-0282 (online) http://jssidoi.org/jesi/

2019 Volume 7 Number 1 (September)

http://doi.org/10.9770/jesi.2019.7.1(29)

\section{Discussion}

The influence of information alternative on delay consumption (H1) is not supported. This research result is inconsistent with the previous research result. It cannot show a significant positive relationship between the search of information alternative and the decision of product purchase delay. Most of the consumers stated that the information from electronic media, non-electronic media, and social media does not affect their choice of product purchasing decision. Other information for products is usually used as a complement and it is not used as reference for choosing the product. Consumers tend to ignore other alternative information if the condition of the product is perceived as incompatible with themselves and the people around them. They are only guided by the opinions and views of the people around them. Therefore, this alternative additional information is not related to their decision to delay the purchase of fashion products. So, although a lot of alternative information is related to the product they want, they will not pay attention if the surrounding environment has not adopted the new model. This research result is also inconsistent with the result from Greenleaf and Lehmann 1995) who stated that people delay their consumption to obtain data or information. Consumers will feel more satisfied and not confused about their decision when they get more information (Jacoby, Speller and Kohn, 1974). Consumers will continually collect information if the cost of getting the information is smaller than the benefit they receive.

The influence of time pressure on delayconsumption (H2) is supported. This research result shows that time pressure has a significant positive influence with the decision of product delay. When consumers feel that they do not have enough time to make decision to purchase desired product, consumers tend to delay it. This time limitation appears because consumers do not have much time devoted to choose some desired product alternatives with the same relative uniqueness, there are other priorities that must be done so that the purchase of the product has not gotten a portion of time, and consumers are also faced with other things urgent when shopping. In relation with this time pressure, consumers will perceive pressure at a time if they are only spending their time shopping while waiting for the next lecture or class. Therefore, in such conditions, consumers tend to be in hurry and they perceive that the time to choose products is relatively insufficient, so they will not buy the product at that time. This research result is consistent with the result from Dhar and Nowlis (1999) who did a research that aims to test the effect of time pressure on choice deferral. The study that was conducted is analyze the cause of delay under time pressure, how degree and the type of conflict choice moderate this relationship, and how the decision process mediates the relationship. The result shows that when conflict occurs, time pressure will decrease choice deferral by increasing the attention on the uniqueness of product display.

The influence of stock out and delayconsumption (H3) is supported. When the product that is perceived by the consumer is getting rare, the higher the intention toward delay. The research result shows that this hypothesis is supported. This result supports the study conducted by Walter and Grabner (1975) which also shows the main reaction taken by consumers when facing stock out, namely switching brands and buying cheaper products, buying products at the same price, buting the same brand but with a different size, and delay purchases. This research result also supports Fitzimon (2000) which stated that perception of stock out which is a situation of loss of products from the market will call on consumers to delay their purchases. Stock out is a condition that indicates the inability of marketers to provide sufficient quantities of product to consumers when they want to buy the product.Innovative product can be successfully accepted by consumers when they have the convenience to buy directly. When consumers have got the information about innovative product and have a positive attitude toward the product, but they are unable to meet the product at the market or the store, it will discourage them from buying it. It is important to be known by marketers, that product success also lies in the ability to supply goods on the market. When consumers perceive difficulties in getting the products on the market, they will delay the purchases.

The influence of self-control on delayconsumption (H4) is supported. The causal relationship between the variables of self-control and delay consumption shows that it has a significant positive coefficient. Baumeister 


\section{ENTREPRENEURSHIP AND SUSTAINABILITY ISSUES}

ISSN 2345-0282 (online) http://jssidoi.org/jesi/ 2019 Volume 7 Number 1 (September) http://doi.org/10.9770/jesi.2019.7.1(29)

(2002) defined self-control and self-regulation as a capacity to give condition alternative and certain response. Self-control is a pattern of response that is started to begin to replace something with another. Self-control needs to be owned by someone when facing an impulse buting situation. This self-control can be done by reducing desire and willpower. Hoch and Loewenstein (1991) described how consumers try to control themselves in facing the choice of time-inconsistency and explained consumers' impatience using the model of decision making theory. This model explains how and why consumers experience can increase the desire for products and temporary rejection of long-term choices. Consumers self-control is framed in two psychological forces, which is reduce desire and willpower. This research result shows that the relationship between self-control and consumption delay is positive. It means that someone who has a good self-control tends to never rush into his decision. The best way a consumer can avoid purchasing behavior is to stay away from situations that might increase the desire to approach the behavior. This avoidance can be done both physically and sensory. Physically, consumers do not approach or go to the store and do not try to see or listen to the information about the product they want. This is consistent with the results of research that is conducted by Ariely and Wertenbroch (2002).

This research result shows that the decision of product purchase delay has a positive relationship with consumer affection response. There are two responses that arise from this delay. Some consumers stated that they enjoy and comfortable with the decision of product purchase delay they did. The reason is, they can have many opportunities to get more benefits. Some others also stated that delay caused them to feel uneasy and disappointed. They feel uneasy because of the possibility of the product being targeted by someone els, and there is a feeling of jealousy if someone else has used the product they want. This result is consistent with the delay concept which does not always have a negative impact on consumers. But there are some conditions that consumers can experience a delay situation. First, if consumers delay the consumption of products that are hedonic or pleasant, consumers do not perceive that delay is an unpleasant thing. Second, consumers do not feel that delay is something resent if hey have the certainty to consume it. In other words, consumers are not only imagining consuming it. Third, if the product that the consumption is delayed is around us, then we do not perceive the delay. Fourth, Shu (2005) argued that delay is not a problem for someone if they are looking for the right time to consume it in the future. Consumers will not get the pleasure if they consume it immediately.

\section{Conclusion}

This research result generally supports the model of delay consumption with the antecedent of information alternative, time pressure, stock out, and self-control, and response as a consequence of product consumption delays. The delay consumption model which integrates from various theoretical and empirical studies can add to the existing theoretical model of delay.

This research uses the data collected from 165 respondents. The research result shows that the strongest factor that affects consumption delay is time pressure, which is $96.9 \%$.It shows that consumers who are faced with time limitations will be increasingly difficult to make purchases, which is different with consumers who have relatively much free time and will be easily make purchases. Consumers' responses toward delay are in balance between positive and negative responses. It shows that consumers emotionally respond to delay in purchases in different ways. For most consumers in the category of Generation $\mathrm{Z}$ (net generation), products that are delayed are not only the hedonic ones, but also the utilitarian. The Generation $\mathrm{Z}$ (net generation) is so familiar with the use of digital technology and social media. This generation has a very open-minded thinking. They are also spontaneous to express their feelings and mind. They are the most connected, educated, and up-to-date generation. Generation $\mathrm{Z}$ really utilizes the existence of smartphones/gadgets to get the goods or products or services they want. The average of Generation $\mathrm{Z}$ likes products that they think are cool. Thus, the delay behavior is very common in this net generation. 


\section{ENTREPRENEURSHIP AND SUSTAINABILITY ISSUES}

ISSN 2345-0282 (online) http://jssidoi.org/jesi/ 2019 Volume 7 Number 1 (September)

http://doi.org/10.9770/jesi.2019.7.1(29)

\section{Research limitations and recommendation for future research}

This research only uses consumers' settings with the research objects of hand phone, laptop, and fashion. From the first pre test result, it is known that the case of delay consumption also occur in many women and men who have potential income. Cultural factors which also have an influence toward delay consumption as presented by Shu (1995) are not included in the research variables. For further research, it is best to include cultural factors in the research about delay.. For further research, the use of this variable needs to be tested once more to get the desired relationship. This is important to be done to ensure that this variable can indeed affect the delay of purchase.The results of many previous researches in delay include situational variable for consumers in the service industry. For research settings on tangible products (goods), situational variable should also be included in the research model as a variable that moderates the relationship of delay decision and consumer response.

\section{References}

Ariely, D. and K. Wertenbroch (2002). Procrastination, deadlines and performance: Self-control by precommitment. Psychological Science, 13(3): 219-224. https://doi.org/10.1111/1467-9280.00441

Baumann, A. A., \& Odum. A.L. (2012). Impulsivity, risk taking and timing. Behavioural Processes, 90: $408-414$. https://doi.org/10.1016/j.beproc.2012.04.005

Baumeister. R. F. (2002). Yielding to templation: Self control failure; impulsive purchasing and consumer behavior. Journal of Consumer Research, 28 (March): 670-676. https://doi.org/10.1086/338209

Bentler, P.M. (1995). EQS structural equations program manual. Encino, CA: Multivariate Software.

Cooper, D. R., \& Schindler, P. S. (2003). Business Research Methods (8 ${ }^{\text {th }}$ Edition). Boston: McGraw-Hill. Companies, 345p.

DeHart, W. B., \& Odum, A. L. (2015). The effects of the framing of time on delay discounting. Journal of the Experimental Analysis of Behavior, 103: 10-21. https://doi.org/10.1002/jeab.125

DeHart, W. Brady. (2017). Identifying the Underlying Components of Delay Discounting Using Latent Factor Modeling. All Graduate Theses and Dissertations, 6339. https://digitalcommons.usu.edu/etd/6339

Detikfinance https://finance.detik.com/berita-ekonomi-bisnis accessed on November 2018

Dhar. R., \& Nowlis, S. M. (1999). "The effect of time pressure on consumer choice deferral,” Journal of Consumer Research, Vol 25 (March), pp: 369-84. https://doi.org/10.1086/209545

Fitzsimons, G.J. (2000). Consumer Response to stockouts. Journal of Consumer Research, 27: 249-266. https://doi.org/10.1086/314323

Friedel, J. E., DeHart, W. B., Madden, G. J., \& Odum, A. L. (2014). Impulsivity and cigarette smoking: Discounting of monetary and consumable outcomes in current and non-smokers. Psychopharmacology, 231(23): 4517-4526. https://doi.org/10.1007/s00213$\underline{014-3597-z}$

Friedel, J. E., DeHart, W. B., Mahamane, S, Odum, A. L., \& Jordan, K. (2015, March). Blue Goes Green I: increased delay discounting for better air quality. Poster presented at the Intermountain Sustainability Summit 6th Annual Meeting, Ogden, UT.

Gast, D. L., \& Ledford, J. R. (2014). Single case research methodology: Applications in special education and behavioral sciences. (2 $2^{\text {nd }}$ Ed). New York: Routledge, 345p. 


\section{ENTREPRENEURSHIP AND SUSTAINABILITY ISSUES}

ISSN 2345-0282 (online) http://jssidoi.org/jesi/ 2019 Volume 7 Number 1 (September)

http://doi.org/10.9770/jesi.2019.7.1(29)

Greenleaf, E. A., \& Lehmann, D. R (1995). Reasons for substantial delay in consumer decision making. Journal of Consumer Research. 22(2): 186-199. http://dx.doi.org/10.1086/209444

Hair, Jr., Anderson, R.E., Tatham, R.L \& Black, W.C. (1998). Multivariate Data Analysis. New Jersey: Prentice-Hall International, Inc., $152 \mathrm{p}$.

Hirschman, E. C., \& Holbrook, M. B. (1982). Hedonic consumption: Emerging concepts, methods, and propositions. Journal of Marketing, 46: $92-101$. http://dx.doi.org/10.2307/1251707

Hirsh, J. B., Guindon, A., Morisano, D., \& Peterson, J. B. (2010). Positive mood effects on delay discounting. Emotion, 10(5): 717-721. http://dx.doi.org/10.1037/a0019466

Hoch, S.J., \& Loewenstein, G.F. (1991). Time-inconsistent preferences and consumer self-control, Journal of Consumer Research 17: 492507. https://doi.org/10.1086/208573

Hornick, J. (1984). Subjective vs objective time measures: a note on the perception of time in consumer behavior, Journal of Consumer Research, 11(1): 614-18. https://doi.org/10.1086/208998

Horton, R.L. (1984). Buyer behavior: a decision making approach. Ohio: Bell and Howell Company, 312p.

Hui. M. K., Thakor, M. V., Gill, R. (1998). The effect of delay type and service stage on consumers' reactions to waiting. Journal of Consumer Research, 24 (March): 469-79. https://doi.org/10.1086/209522

Indonesian Central Bureau of Statistics, 2018. http://ghdx.healthdata.org/organizations/central-bureau-statistics-indonesia

Jacoby, J., Speller, D. E., \& Kohn, C. A. (1974). Brand choice behavior as a function of information load. Journal of Marketing Research, 11(1): 63-69. https://psycnet.apa.org/doi/10.2307/3150994

Joseph, R. C. (2005). An Examination of Non Adoption and Decision Inertia: A Web Based Perspective. Doctoral Dissertation Unpublished. New York: The City University of NewYork.

Joseph, R. C. (2010). Individual Resistance to IT innovations. Communication of the ACM, 53(4): 144-146. https://doi.org/10.1145/1721654 1721693

Killeen, P. R. (2015). The arithmetic of discounting. Journal of the Experimental Analysis of Behavior, 103: 249-259. https://doi.org/10.1002/jeab.130

Kirby, K. (2009). One-year temporal stability of delay-discount rates. Psychonomic Bulletin \& Review, 16: 457-462. https://doi.org/10.3758/PBR.16.3.457

Kivetz, R., \& Simonson, I. (2002). Self-control for the righteous: Toward a theory of precommitment to indulgence. Journal of Consumer Research, 29: 199-217. https://doi.org/10.1086/341571

Lewin. K. (1951). Field Theory in Social Science. Selected Theoretical Papers. New York Harper. https://trove.nla.gov.au/work/14289400

Lippincott, J.K. (2005). Net generation and libraries. in Educating the net generation. Diana G. Oblinger \& James L. Oblinger (Eds.). S.1.: Educause. Retrieved April 1, 2011, from http://www.educause.edu/educatingthenetgen/

Loewenstein G., \& Prelec, D. (1992). Anomalies in intertemporal choice: Evidence and an interpretation. The Quarterly Journal of Economics, 107: 573-597. https://doi.org/10.2307/2118482

Loewenstein. G. (1987). Anticipation and the valuation of delayed consumption. The Economic Journal, 97(38): 666-84. https://doi.org/10.2307/2232929

Menon, S., \& Kahn, B.E. (1995). The impact of context on variety seeking in product choice. Journal of Consumer Research, 22: $285-295$. https://doi.org/10.1086/209450

Nowlis. S.W., Mandel, N., \& Mc.Cabe, D.B. (2004). The effect of a delay between choice and consumption enjoyment. Journal of Consumer Research, 31(Dec): 502-510. https://doi.org/10.1086/425085 


\section{ENTREPRENEURSHIP AND SUSTAINABILITY ISSUES}

ISSN 2345-0282 (online) http://jssidoi.org/jesi/ 2019 Volume 7 Number 1 (September)

http://doi.org/10.9770/jesi.2019.7.1(29)

Odum, A. L. (2011). Delay discounting: Trait variable? Behavioural Processes, 87(1); 1-9. https://doi.org/10.1016/j.beproc.2011.02.007

Osuna, E. E. (1985). The psychological cost of waiting. Journal of Mathematic Psychology, 29(1): 82-105. https://doi.org/10.1016/0022$\underline{2496(85) 90020-3}$

Paglieri, F., Addessi, E., Sbaffi, A., Tasselli, M. I., \& Delfino, A. (2015). Is it patience or motivation? On motivational confounds in intertemporal choice tasks. Journal of the Experimental Analysis of Behavior, 103: 196-217. https://doi.org/10.1002/jeab.118

Purwanto, B. M. (2002). The Effect of Salesperson Stress Factors on Job Performance. Jurnal Ekonomi dan Bisnis Indonesia, 17: 150-169. https://doi.org/10.22146/jieb.6730

Ram, S., \& Sheth, J.N. (1989). Consumer Resistance to innovation: the marketing problem and its solutions. Journal of Consumer Marketing, 6: 5-14. https://doi.org/10.1108/EUM0000000002542

Ram, S. (1987). A model of innovation resistance. Advances in Consumer Research, 14: 208-212. http://acrwebsite.org/volumes/6688/volumes/v14/NA-14

Rogers, E.M. (2003). Diffusion of Innovations. $5^{\text {th }}$ edition. New York: The Free Press, 357p.

Rook, D. W. (1987). The buying impulse. Journal of Consumer Research, 14: 189-99. https://doi.org/10.1086/209105

Shamosh, N. A., DeYoung, C. G., Green, A. E., Reis, D. L., Johnson, M. R., \& Gray, J. R. (2008). Individual differences in delay discounting: Relation to intelligence, working memory, and anterior prefrontal cortex. Psychological Science, 19: 904-911. https://doi.org/10.1111/j.1467-9280.2008.02175.x

Shu. S, (2005). Choosing to consume later: determinants of future-biased choice. Advances in Consumer Research, 32: 67-68. http://www.acrwebsite.org/volumes/9029/volumes/v32/NA-32

Sugandini, D. (2013). Karakteristik inovasi, pengetahuan konsumen, kecukupan informasi, persepsi risiko dan kelangkaan dalam penundaan adopsi inovasi pada masyarakat miskin. Dissertations, DIS 246-H-2012. Universitas Gadjah Mada, Yogyakarta. http://etd.repository.ugm.ac.id/index.php?mod=penelitian_detail\&sub=PenelitianDetail\&act=view\&typ=html\&buku_id=58899

Sugandini D., Sudiarto, Surjanti, J., Maroah, S., \& Muafi. (2018). Intention to delay: The context of technology adoption based on android. International Journal of Civil Engineering and Technology, 9(3): 736-746. http://www.iaeme.com/IJCIET/index.asp

Walter, C.K., \& Grabner, J. (1975). Stockout cost models: empirical tests in a retail situation. Journal of Marketing, 39: 56-68. https://doi.org/10.2307/1250902

Wesley, M. J., \& Bickel, W. K. (2014). Remember the future II: Meta-analyses and functional overlap of working memory and delay discounting. Biological Psychiatry, 75: 435-448. https://doi.org/10.1016/j.biopsych.2013.08.008

Dyah SUGANDINI currently is a lecturer and researcher at Management Departement, Economic and Business Faculty of Universitas Pembangunan Nasional veteran Yogyakarta. Completed Doctoral Program from Universitas Gadjah Mada Indonesia, 2013 and Master of Management Science from Universitas Gadjah Mada Indonesia, too, 2003. Her area of expertise is Marketing Management and entrepreneurship.

ORCID ID: 0000-0003-0611-882X 


\section{ENTREPRENEURSHIP AND SUSTAINABILITY ISSUES}

ISSN 2345-0282 (online) http://jssidoi.org/jesi/ 2019 Volume 7 Number 1 (September) http://doi.org/10.9770/jesi.2019.7.1(29)

Christin SUSILOWATI currently is a lecturer and researcher at Management Departement, Economic and Business Faculty of Brawijaya University Malang. Completed Doctoral Program from Brawijaya University Indonesia in 2010 and Master of Management Science from Airlangga University Indonesia in 2002. Her area of expertise is Strategic Management with interest in Strategic Human Resources Management, Marketing Management and Corporate Social Responsibility. The subject that she taught include Strategic Management, and Marketing Management.

ORCID ID: 0000-0002-1189-9221

Argo PAMBUDI currently is assistant professor and researcher at Public Administration Department, Social Sciences Faculty of Universitas Negeri Yogyakarta. Completed Magister Program from Gadjah Mada University Yogyakarta in 1995. His suject area of expertise is public policy and educational Policy.

ORCID ID: 0000-0002-5918-1278

Suranto AW currently is an Associate Professor at Communication Science Department, Faculty of Social Sciences of Universitas Negeri Yogyakarta. Completed Doctoral Program from Universitas Negeri Yogyakarta in 2013 and Master of Communication Science from Padjadjaran University Indonesia in 2000. His area of expertise is Educational Communication.

ORCID ID: 0000-0002-7338-8689

MUAFI currently is a lecturer and researcher at the Universitas Islam Indonesia majoring in Management. He completed his Doctoral Program from Universitas Brawijaya in 2008 and his Master of Management Science from Universitas Airlangga in 1997. His area of expertise is in Human Resources Management with interest in Strategic Human Resource Management, Organisational Behavior, and Change Management. The subjects that he has taught include Strategic Human Resource Management, Strategic Management, and Oganisational Behaviour. He has secured a research grant from the Research and Technology Ministry and Dirjen Dikti Indonesia and Finance Ministry Indonesia. Muafi has owned some publication of indexed by Scopus and can be contact at: muafi@uii.ac.id

ORCID ID: 0000-0002-5078-4670

Mukarto SISWOYO currently is an associate professor in Public Administration field, in Universitas Swadaya Gunung Djati, Cirebon, West Java, Indonesia. He graduated with doctoral degree from Universitas Pasundan, Bandung in 2015. He masters in state administration, public policy, regional autonomy, and local government management.

ORCHID ID: 0000-0002-05223-4522

Register for an ORCID ID:

https://orcid.org/register

Copyright (C) 2019 by author(s) and VsI Entrepreneurship and Sustainability Center

This work is licensed under the Creative Commons Attribution International License (CC BY).

http://creativecommons.org/licenses/by/4.0/

CC) (i) Open Access 